\title{
Retail Heritage and Tourism: The Emblematic Shops of Barcelona
}

\author{
Carles Carreras \\ Urban Retail Observatory (UCOB) \\ Universitat de Barcelona \\ Lluís Frago \\ Urban Retail Observatory (UCOB) \\ Universitat de Barcelona
}

In this paper, the authors analyze the local policies of Barcelona in regard to the conservation of the emblematic stores. First, they study the difficulties to consider heritage the highly dynamic economic activities, and the impact of the Barcelona's tourist success on the conservation of some establishments. The strong impact of the real estate market into the retail business is also analyzed, especially the rent cost in order to maintain shops open. Some conclusions are presented trying to combine tradition and modernity in the urban retail activities.

Keywords: Barcelona, emblematic shop, heritage, tourism

\section{INTRODUCTION}

The complex interrelations between the city and retail have been the subject of study of our working group since 1986, following an exhaustive investigation into the areas of commercial concentration in Barcelona, financed by the Chamber of Commerce (Carreras, Domingo, Sauer, 1990). It was defined as a shopping town a few years before the Olympic Games and many more before the city's tourist success, which many people believe is dying, mostly those who are killing it: the public opinion makers and some undefined "neighbors" lacking coherence. Between 1997 and 1999 we carried out an inventory of elements of scenic interest for the city of Barcelona's Urban Landscape Agency, in which, among other elements, some of the so-called emblematic retail establishments - historical according to the definition coined by the agency from a formal architectural point of view (AA.VV., 1999) - were collected. The agency, within the program of beautification of the public space of the city set up before the Olympic Games, had organized the campaign "Barcelona ponte guapa!", in which stores of some architectural or design value, aged around one hundred years or more and which had not changed their decoration, were collected. In the publication of the Commercial Atlas of Barcelona, in 2003, this campaign was collected and evaluated (Carreras, 2003). In the meantime, the end of the moratorium of the law of liberalization of rents in Spain, the famous Boyer decree of $1985^{1}$, together with the passage of time, that is, thirty years until its final application, and the economic and social changes generated by integration into the European Union in 1986, the monetary union in 2001, the global financial crisis of 2007 and retail apocalypses (Philipose, 2019) initiated a wave of closure of these (and many other establishments) that has aroused 
enormous media furor. Such furor is, quite incomprehensibly, part of the unwavering continuity of local (and also regional, at the level of Catalonia) trade policy, despite the rotation of socialist, nationalist and populist governments.

Without avoiding the media or popular spotlight, the Urban Retail Observatory of the University of Barcelona (UROB) tries to generate knowledge regarding this aspect of the always mistreated retail sector; this task is carried out on a local and regional, as well as national and international level ${ }^{2}$. The initial scheme was formulated at the Rio de Janeiro seminar in June 2006.

To this end, this article addresses the adjustment of the concept of heritage to retail activity, as well as the impact of the success of tourism on the economic dynamics of the city and its commercial establishments, and then considers the importance of the real estate market for the location of economic activities. Once the role of retail trade as an economic activity has been reaffirmed, the impact of the city's different time periods is addressed, as well as the role of the social appropriation and reappropriation of urban space in the way of life in the city. This allows us to advance some initial conclusions towards the future in order to open up academic debate.

\section{THE DIFFICULTY OF ASSIMILATING STORES AS HERITAGE}

Numerous misconceptions about retail activities and establishments exist and are often mixed up. It is frequently overlooked that this is an economic activity that seeks to minimize expenditure and maximize income in order to maintain and, if possible, increase profit. It is overlooked that there are diverse strategies to achieve this goal that allow for a choice of positions among competitors and collaboration between different businesses. It is overlooked that commodity trading activities do not constitute a public service, but mostly, in the capitalist economy, seek a balance between supply and demand to their own benefit. Some overlook the social and cultural values implicit in the exchange of goods and services, while others may overestimate them, overlooking their purely economic and materialistic basis. Consequently, the classification of retail establishments becomes more complex than that of economic activities carried out neatly by the different statistical services on a local, national or international level, since, in addition to the product or service offered, the sales area, the absolute or relative location, the frequency of use or the type of legal relationship between the seller and its suppliers, and the target market or segment of demand to which it is mainly addressed, can be taken into account. At the very least, the weight of the real estate market in the expenditure of the retail company must be taken into account.

In urban retail, all this complexity, commonly ignored in whole or in part, increases even more. The relationship between the city and commercial activities is old, enduring and intense, and lies somewhere between symbiosis and parasitism. The free market that would govern the exchange activities is no longer an abstract myth but a concrete reality in certain agents and strategies, with characteristics common to all cities and particularities in each one of them. The absence and scantiness of deep and rigorous studies from the Social Sciences, essential within this matter into which the symbolic and patrimonial role that some commercial establishments represent in many cities is inserted, seems unjustifiable.

The American urbanist Kevin Lynch (1918-1984) established the need to take into account urban landmarks, points of reference outside the observer, which could be of a very different nature depending on the person, as a means to gain understanding of the city image (Lynch, 1960; pp. 75-78 in the Spanish translation). Commercial establishments of all kinds are undoubtedly landmarks, for the situation and knowledge of the city for many of its citizens and visitors. Their exposure to the public space of the street, reinforced by the commercial display of shop windows, genre, advertising and signs, makes them particularly visible. Commercial signs are almost as old as the activity, since shops requires their rapid and effective visualization in order to attract buyers; from the paintings in Roman shops, such as those preserved in Pompeii, or the medieval signs, up to the neon and luminous signs of modernity. In this way, the commercial establishments, as landmarks for daily or sporadic itineraries, become the city itself, they become heritage in a certain way, part not only of the city, but also of the image that its citizens have of it, 
and therefore of their memory; citizens and visitors make the image of these establishments their own, they internalize it and use it as a reference to situate themselves within the city.

The stores, private enclaves in the public space, facades that outline the streets and squares of the cities, regardless of their size and appearance, are part of the collective memory of citizens and even visitors; tourist guides, international or local, contribute to maintaining a selective fixation on their leisure and shopping sections. For this reason, when a commercial establishment, a bar, a restaurant or a clothing store closes, what was an urban landmark for many, disappears, somehow emptying the historical memory, losing a historical reference of daily life, even for those who have never been customers of that establishment. Hence the media coverage of the closures of certain establishments

In the same way that the French urbanist Françoise Choay (b. 1925) highlighted the fact that interest in artistic and monumental heritage appeared at the time of the destruction associated with the events of the French revolution (Choay, 1980), conservationist claims regarding urban commercial heritage appeared at the time of renovation and urban change. In Barcelona, after the apparent success of the 1992 Summer Olympics, the great contemporary transformation was launched, which has made it possible to speak of a "disputable and disputed Barcelona model" (Bohigas, 1985; Busquets, 1992; Capel, 2005; Carreras, 2012). It all began, naturally, in the historic city, administratively called the Old City, the result of one of the two axes of urban policy, that of the renewal of the city center, along with the monumentalization of the periphery. The latter essentially focused on public spaces, while the former fully affected private spaces, for residential or commercial use. Thus, since the early 1990s, work began on drawing up lists of private commercial establishments that might be of special interest due to their age or their external or internal artistic qualities.

The municipal institute of urban landscape and quality of life, which manages the city's heritage catalogue, took the initiative in defining a number of establishments to be denominated emblematic (Ferrer, 2001). Since the beginning of the campaign Guapos per sempre (Handsome forever) in 1994 and until 2007, year of the publication of the second edition of the commemorative book of the city council program, 125 plaques were awarded to establishments that were considered of this type. All of the awarded shops met the basic requirements: first and foremost, they were over fifty years old and had carefully maintained the original character of their external appearance; secondly, they were still on the same site and worked within the same branch of the commercial sector. Years earlier, in 2003, for the publication of the Atlas of Barcelona, a total of 86 emblematic establishments were identified (Carreras, 2003), approximately the same as those that formed the list of establishments in the first edition of the book Guapos per sempre (2004) and which only listed those that were over 100 years old. The plaques laid on the sidewalk in front of the entrance of the establishments were only an acknowledgement to support the owner in conservation but did not provide any level of protection.

Ever since, the censuses on this type of establishment have been changing and have perhaps become increasingly thorough, for which reason more and more establishments have been catalogued, yet no more plaques have been laid. The last census carried out by Barcelona City Council in 2012 identified a total of 454 establishments, all of them located in Ciutat Vella, Eixample, Sant Andreu, Gràcia, Sant Martí, Sarrià, Sants-Montjuic and les Corts, that is, historic Barcelona and in the centers of the old municipalities annexed to the city between 1897 and 1902. A much longer list than that of 2007, as the cataloguing criteria were extended, identifying 118 "emblematic" establishments, and 336 establishments that form part of two new types of mention: 154 considered as "outstanding" establishments and the rest "mentioned", with the "outstanding" ones meeting fewer criteria to be catalogued. $92 \%$ of the emblematic establishments are located in the Districts of Ciutat Vella and Eixample, while in the case of the outstanding establishments, the figure stands at $77 \%$ in these two districts. As a result, as the cataloguing criteria have become laxer, their territorial distribution has expanded ${ }^{3}$.

Between 1997 and 1999, the University of Barcelona's Urban Retail Observatory carried out a research project funded by the Urban Landscape Institute, which made it possible to contrast and discuss the criteria to be used in assessing elements that may be significant in the cities' landscape, beyond those for cataloguing and conserving monuments. The aim was to carry out a first census of elements of the urban landscape of the city of Barcelona, combining the knowledge and criteria of university scholars 
(geographers, historians, anthropologists, art historians) with the daily experience of citizens, gathered through a local newspaper of great circulation, El Periódico de Catalunya, and the local television network BTV.

This led to an initial collection of visual elements that marked the landscape of the city as a whole (the characteristic black and yellow color of the taxis, or the tiles of the pavement on the sidewalks) or of some specific places regularly distributed throughout the urban area (small mural chapels of saints, a commercial luminous thermometer or some commercial advertisements). No protection was contemplated either, but their collective value was recognized, and their conservation was encouraged, in addition to the recording of images and related information (Carreras, 2001, pp. 19-20 and 49-50; AA.VV., 1999, pp. 175-176). Thus, a less monumental vision of the urban landscape was promoted, beyond artistic styles and established authors, and therefore more democratic by promoting citizen participation and recognizing the values of daily life.

For the functionality of retail establishments, and for the knowledge of the commercial structure of a city, it is very important to take into account, the dynamics of the market, in general, as well as the changes in the behavior and tastes of the consumers. Good shopkeepers are compelled to be constantly aware of all kinds of changes, to keep up to date with innovations in products and services, without forgetting even the formal and decorative aspects of their establishments, and advertising, which logically opposes any kind of conservationism, making heritage conservation difficult. With regard to the specific assessment of Barcelona's emblematic establishments today, it is important to analyze the variables that act as a determining factor in the fate of these establishments and that place the debate on their future far beyond the purely technical and architectural, but also the nostalgic and in the media. The times and rhythms of architecture and art are always much slower than those of economic activities and those of social fashions and customs, and they obey totally different causes.

In order to properly analyze the case of Barcelona, it is necessary to address at least two different and complementary aspects. On the one hand, the effects of the behavior of shopping and consumer tourism in the city. On the other hand, the consequences of the evolution of the real estate market in terms of the increase in the value of land and premises and rentals.

\section{TOURISM AS A FACTOR THAT MULTIPLIES CONSUMPTION AND PROMOTES HERITAGE CONSERVATION}

Without a doubt, Barcelona is today the main tourist city in Spain with around 12 million tourists and visitors per year (Barcelona City Council, 2019) and the fourth in Europe, after London, Paris and Istanbul, and the twelfth in the world, in a ranking that is probably more difficult and debatable. $50 \%$ of the tourists who visit the city do so for holidays, $40 \%$ for business and $10 \%$ for fairs and congresses.

Regarding consumption, according to the Mastercard Global Destination Cities Index 2019, Barcelona was the eighteenth largest city in the world in terms of international tourist spending. This same agency states that the city of Barcelona is the second largest city in the world in terms of international tourist expenditure per resident in the city, with 2,793 euros per inhabitant ${ }^{4}$. This fact means that in spite of the short duration of individual stays in the city, tourists become an important and permanent consumer group throughout the year in the city (Carreras et al, 2016). Despite the diversity of the socio-economic and cultural profiles of Barcelona's tourists, consumption patterns are more similar among them than if the variable considered were age, for example.

Based on the data provided by the companies that own the credit cards that have been processed by Turisme de Barcelona (2019), it is believed that 33\% of tourist expenditure per person is made in

commercial establishments, a percentage that would represent an average of 64 euros per day ${ }^{5}$. Obviously not all tourists spend in the same way, in the case of Barcelona, Chinese and Russians were the nationalities with the highest spending in the city; likewise, despite the fact that the majority profile of tourists in Barcelona is that of people between 25 and 34 years old, representing 34\% of the total, older tourists consume more in commercial establishments than younger ones. 
These figures are by no means negligible when it comes to understanding the transformations that Barcelona's commercial activities have undergone, as a whole, and particularly in some central sectors. The daily per capita expenditure of tourists in commercial establishments is logically much higher than that of the city's residents, which is why commercial establishments have increasingly focused on tourists $^{6}$. The process of modernizing products and services, sales techniques and the commercial display has been especially visible during these last years of social and economic crisis that have directly affected the consumption capacity of Barcelona's citizens and Spaniards in general. Despite the fact that there have been specific adaptations of commercial establishments to the consumption requirements of tourists, as has already been shown by analyzing the commercial structure of the Raval district (Carreras et al, 2016), in general terms the very significant presence of tourists in the city throughout the year and the growing diffusion of the places consumed by visitors leads one to think that in general terms, except in the most peripheral districts, the whole commercial structure of Barcelona has benefited from the income generated by tourism.

The adaptation of some of Barcelona's emblematic establishments to the consumer tourist has also acted as a conservative and even invigorating element and not as it is spread in some media, weakening these establishments or extinguishing them. On some occasions it has been possible to determine how some traditional commercial establishments have been gentrified, turning antiquity into an attractive patina (Martínez-Rigol, Moreno, 2008). Many of the best-known emblematic establishments have become tourist attractions, as a result of their promotion in the guides and articles in newspapers and magazines of all kinds. This is perhaps especially clear in the case of some restaurants, as the case illustrated in figure 1 .

\section{FIGURE 1 \\ COVER OF THE BARCELONA TOURIST GUIDE EDITED BY LONELY PLANET (2010) WITH THE IMAGE OF THE ENTRANCE OF THE RESTAURANT LOS CARACOLES, AN EMBLEMATIC ESTABLISHMENT OF CIUTAT VELLA}

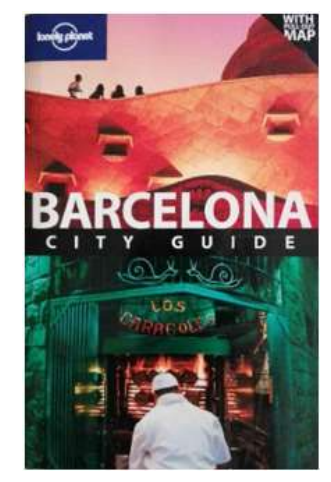

\section{THE IMPACT OF THE REAL ESTATE MARKET ON RETAIL ESTABLISHMENTS}

The real estate market plays a transcendental role in the configuration, evolution and transformations of the city and, therefore, of the retail structure. Commercial premises, like any other site or premises destined for some urban function, for example residential, probably much better known, have experienced a growing process of commercialization and globalization (Bernardos, et al, 2014). Undoubtedly, the commercialization of commercial premises tends to have much less dramatic effects when compared to the housing market, where despite the existence of a greater supply, access to it by a very important part of the demand is very difficult, if not impossible.

The price of commercial premises, logically, is the product of the relationship between supply and demand which, in the case of the real estate market, depends to a large extent on its location, both absolute, within the urban space, and relative, with respect to other similar or competitive locations. This fact explains the formation of the differential rental of the land that has a direct effect on the final price of 
the premises. The formation of the differential rental of land allowed the formulation of the model on land use and location of the Argentine economist William Alonso (1933-1999) in the 1960s. This model, in accordance with its neo-positivist simplification and in an isotropic conception of urban space, established that the activities with the capacity to pay the highest land rents, given their need to be in the most central and frequented places, were the commercial ones.

The role of the real estate market as a driving force in understanding the transformations of Barcelona began in the second half of the 19th century, with the opening up of the surrounding plain to full urbanization through the approval of the Cerdà Plan in 1860 (Tafunell, 1989). Although it has not yet been sufficiently researched, the internationalization of Barcelona's real estate market occurred after Spain joined the EU in 1986, and even more so after the entry into the single currency in 2001, which ended the international currency differential (Bernardos et al, 2014). The tourist success after Barcelona 1992 and the real estate boom at the end of the millennium multiplied the demand for urban properties. Large international real estate companies began to operate in the residential market, but also in other sectors with sufficient demand, such as logistics warehouses and offices, which were deeply affected by the crisis that began in 2007, as well as that of commercial premises, also affected by the depression but less so, especially in the case of the city's more central locations.

The increase in the price of commercial premises as a result of the increased importance of the real estate market has not stopped growing, especially in downtown Barcelona (Figure 2) in spite of the social and economic crisis of 2007. As can be noted, the evolution has been more positive in the symbolic streets of Portal del Ángel and Paseo de Gracia. On some occasions the revaluation of the rental value of the land has been so high that some commercial companies have gone on to buy the properties and subsequently rent them to other commercial chains or locate a store of their chain, as has occurred with the fashion giant INDITEX, in its two properties in the Plaza de Cataluña where a Zara establishment or that of the Apple chain is located.

FIGURE 2

\section{EVOLUTION OF RENTAL PRICES IN EUROS PER M² OF COMMERCIAL PREMISES IN VARIOUS STREETS OF DOWNTOWN BARCELONA}

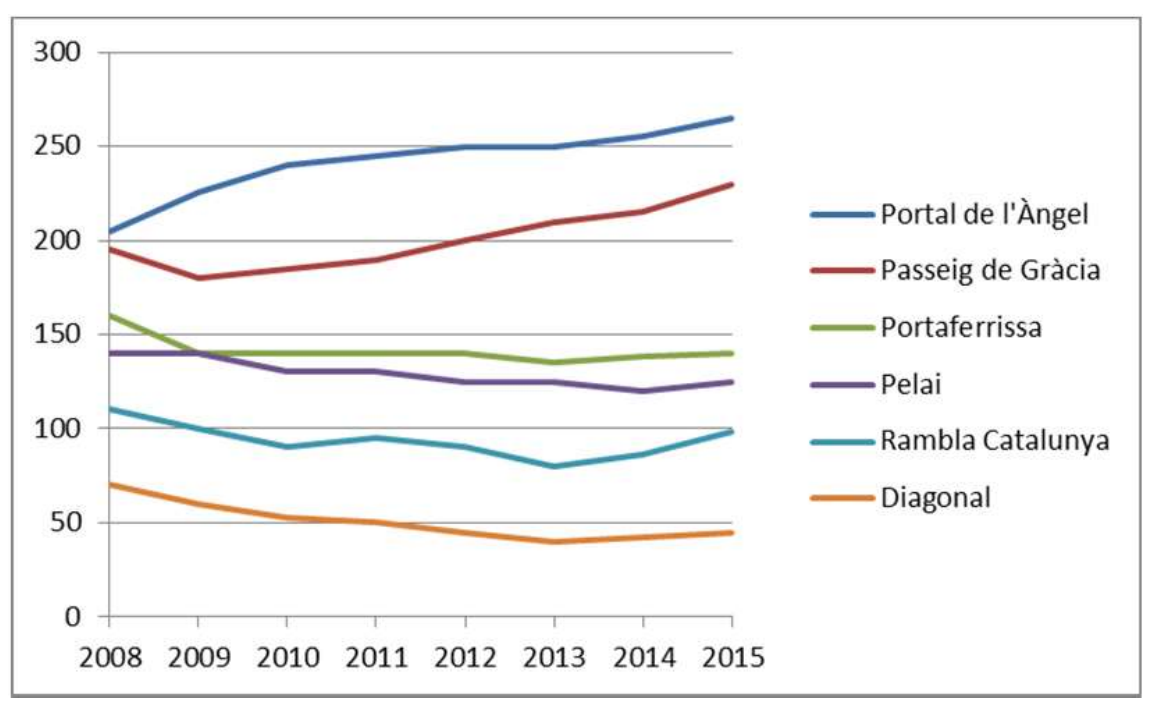

The importance of the real estate market has had its effects on the entire commercial structure of Barcelona, especially on the emblematic establishments, given the age of their contracts and rentals and their predominantly central location. Logically, the effects on commercial businesses have been very different depending on the tenancy regime of the commercial premises. The establishments, whether emblematic or not, under rental regime with contracts prior to 9 May 1985, when the famous Boyer decree was approved, were governed by the urban rental decree 4104/1964, of 24 September, being 
subject, with imperative character, to the regime of forced extension for 20 more years. Later, Law 29/1994 of 24 November 1994 on urban rental, in force since 1 January 1995, eliminated any mandatory requirement of duration or compulsory extension of rental contracts for uses other than housing. The law thus provided for the extinction of old rental contracts and their consequent updating to current market rules, both in terms of rental values and the duration of the contract.

In April 2012, Barcelona City Council conducted a survey of "emblematic" and "outstanding" establishments and found that in $60 \%$ of the cases the tenancy regime was that of rental. Within this group, $60 \%$ of the businesses were also governed by old rents, representing $31 \%$ of the 272 establishments catalogued as "emblematic" or "outstanding". These establishments were thus affected by the expiry established by the third transitional provision of the LAU (Llei 29/1994). These same data reveal that in $40 \%$ of cases, the businessman-merchant of the emblematic and outstanding establishments is also the owner of the commercial premises, so the problem does not exist; he only has the possibility of doing a good real estate business, in coherence with the phase of financial capitalism that has succeeded the commercial and industrial one.

The situation is therefore different in the case of establishments that are open on rented premises than in the case of establishments that are owned. In the former, it is difficult to explain with certainty when the closure of the business is due exclusively to an increase in the price of the rental or to a decrease in turnover and profits. In a similar way, but with very different consequences, in retail establishments in owned premises it is difficult to know precisely when the sale is purely for real estate reasons or when these are justified by a decrease in profit or by a loss of interest in the continuity of the business. In view of the closure of the Vinçon establishment on Paseo de Gracia in Barcelona, dedicated to the sale of design products, the owner of the business made a significant point in this regard that the only solidarity that could save the business was to recover the number of customers.

Catalogues and surveys from the administrations, handsomely illustrated journalistic books and media interventions launching Jeremiad protests have neither succeeded in analyzing nor in helping to solve the problem. Since 1985, Barcelona City Council has had three different political administrations and in no case has the problem been foreseen or effective measures taken to help the commercial activity that gives rise to the establishments (the emblematic ones, the outstanding ones and those that are not considered either one or the other). The liberalization of prices and rents has been treated as an inevitable and natural catastrophe and very few have questioned the liberal system that underlies the functioning of the real estate market. The establishment of some municipal tax or rate on the change of activity could perhaps have been a practical measure.

Thus, the price of land and premises continues to be the driving force behind the production of urban space, the logic of which prevails over that of businesses and private activities. Despite the close relations between retail trade and urban life, commercial establishments are private businesses and not a public service, not even those that, like pharmacies or bakeries, had been organized in Barcelona in a gremial and territorial way.

\section{THE RECENT EVOLUTION OF BARCELONA'S EMBLEMATIC ESTABLISHMENTS}

Between 1994 and 2007, a total of 125 commemorative plaques had been granted to further establishments; first to those around 100 years old, then to those close to 50. In 2007, 6 plaques had already been removed due to the transfer or change of business. In contrast, over the last 10 years, 36 more of the establishments considered emblematic have closed, leaving only 83 open at present, that is, two thirds of the total amount (Figure 3). This increase in the closure of establishments coincides with the aforementioned liberalization of rents, but also with the consequences of the 2008 crisis. That does not mean, however, that the media impact has been any less.

From a territorial point of view, the concentration of open and, above all, closed establishments is much greater in the streets of the historic city, and, albeit somewhat less so, in the central sector of the Ensanche of the 19th century. Outside these areas, the presence of listed establishments is practically symbolic, due to the historicist and architectural vision applied. It can also be seen how the streets that 
experience the highest land prices do not house any significant amount of this type of commercial establishments that obey very different rationales from those of the real estate market.

The establishments that have best withstood the changes and crises are those dedicated to pharmaceuticals, restaurants and hotels; these are businesses that maintain a constant, if not increasing, demand, especially the latest ones driven by the aforementioned tourism surge. But even if they remain formally, some establishments have totally changed their commercial activity. Such is the case of the Escribà patisserie, on Barcelona's Ramblas, which in 1986, only six years before the start of the conservationist policy, acquired the premises of the old Figueras pasta factory, installed in 1842 and renovated in the art nouveau style in 1902. Like the Roca jewelry store on Paseo de Gracia, in the rationalist style of the famous architect Josep Lluís Sert (1902-1983), which has become an establishment of the Tous jewelry chain. Like the Reñé cake shop on the Consell de Cent street, which was founded in 1910 and since 2000 has become a restaurant that preserves the façade and some elements of the previous decoration. The policy in these cases clearly protects the architecture but not the commercial activity

\section{FIGURE 3 \\ LOCATION OF THE OPEN AND CLOSED EMBLEMATIC ESTABLISHMENTS AND THE MOST HIGHLY VALUED SHOPPING STREETS IN FIGURE 2}

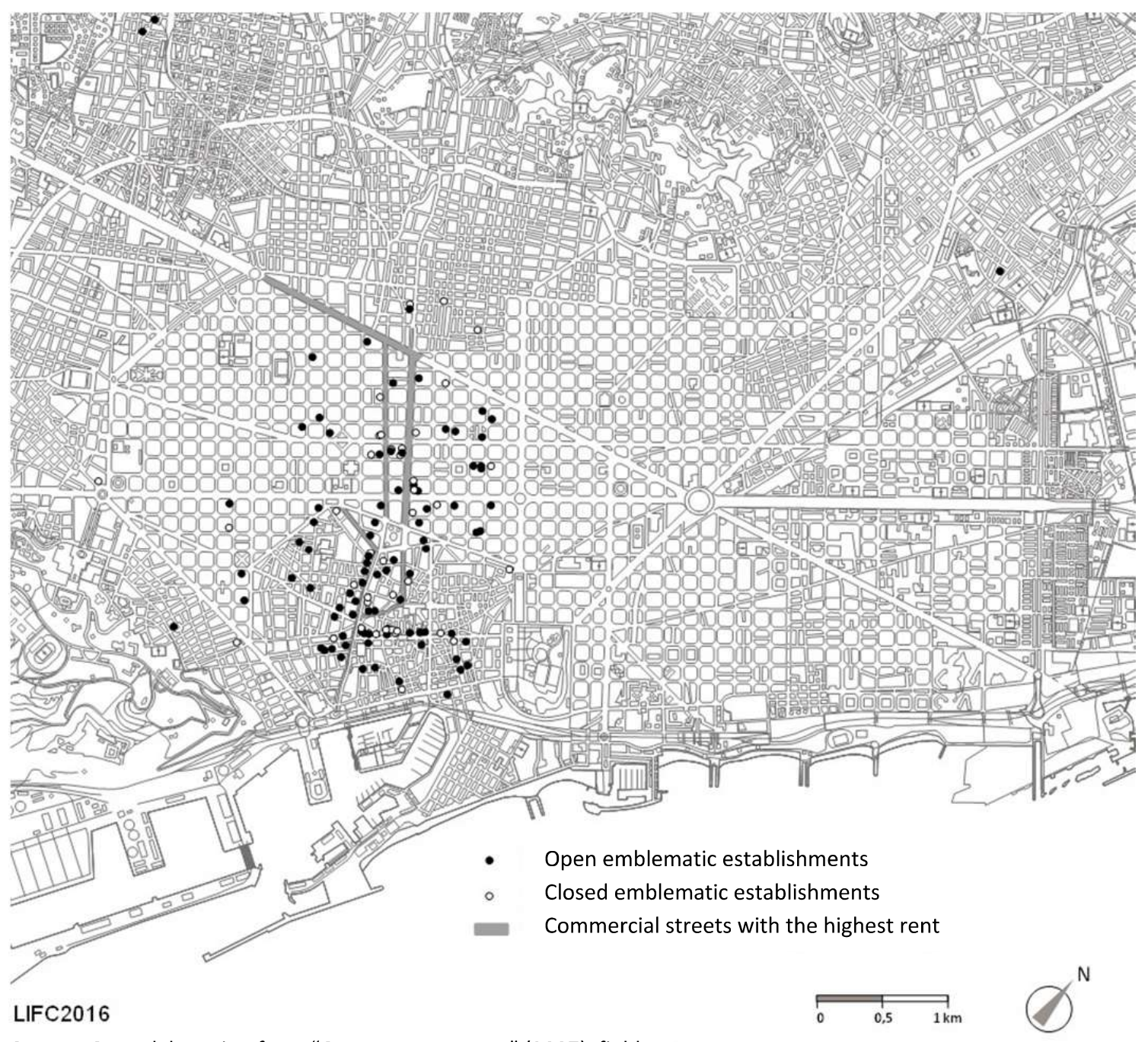

Source: Own elaboration from "Guapos per sempre" (2007), field work and UCOB cartographic base. 


\section{CONCLUSIONS FOR THE FUTURE}

From the case of the city of Barcelona, the heritage and identity character, of urban reference in the daily life of many commercial and service establishments, is fully accredited ${ }^{7}$. The success of tourist consumption appears to be a favorable factor for the conservation of the identifying features of a city, a district or a street, at least in its formal aspects.

The first problem to be addressed is that of an adequate and complete definition of what is to be considered an emblematic establishment. A single, almost exclusively material, architectural criterion presents limitations. In a study of Catalonia's commercial heritage that sought to highlight its role in the memory of everyday life, three different criteria were put forward that were not always fully met. A first criterion, certainly, could be that of the quality and originality of the building in which the establishment is located; a second criterion, already more related to commercial activity, was the artistic quality of the establishment's decoration, advertising and display; a third criterion, fully commercial, was the quality and originality of the products or services offered (Carreras, Moreno and Ariño, 2006).

To these criteria must be added the temporal variable that declines to establish as preferential or normative a style or a moment over others; the dynamic nature of commercial activities and consumption, compels to take into consideration the diversity of tastes and moments, giving space not only to tradition, but also to modernity and innovation. The reason for this is the difficult relationship between the different temporal rhythms in the city and the different appropriations of the urban landscape by citizens and visitors. Particularly complex is the relationship between the permanent nature of the urban and the ephemeral nature of the fashions that blossom in each and every one of the commercial establishments.

Media reactions are not usually helpful in understanding the problems generated by complexity, but tend to respond to specific, immediate and passing interests, often more ephemeral than fashions. These reactions in Barcelona have involved appeals to nostalgia, to the economic logic of commercial companies, and confronting the local populations, the so-called neighbors, with the foreign citizens, tourists, using massification as an argument. Many times the permanent conflict between the "we", more or less identitarian, and the "they", the other, sometimes tourist, sometimes immigrant, is at the base of the media campaigns; a problem very far from the one that refers to the emblematic commercial establishments and their survival in the city. As we have seen, the conservation of emblematic establishments is favored more than harmed by tourist guides and itineraries; this can be corroborated by the daily appropriations that the various groups of tourists make of parts of the city, especially the central sectors.

A more general conclusion regarding the case under analysis and with possible applications to many other cases is the need to overcome the treatment of the problem at the individual establishment level. Commercial activities have, since the beginning of their history, woven dense interrelations between specialties and modalities that have materialized in the formation of fairs and markets, streets and squares, and commercial centers and areas. In this sense, it seems necessary for local administrations to consider taking a step beyond the consideration of the emblematic establishment towards the approach of urbanization, support and conservation of the emblematic commercial street or square. With this, the symbiosis between retail trade and city and urban life would reach a more adequate level of social and political consideration

\section{ENDNOTES}

1. The royal decree drawn up by Minister Miguel Boyer (2/1985, 30 April) was supplemented by the 1994 Urban Rental Law and its consequences clarified by the Supreme Court ruling of 2013.

2. The international seminars of Retail, Consumption and City started in Rio de Janeiro (2006) and continued in Barcelona (2008), Sao Paulo (2011), Naples (2013), Mexico City. (2015), Lisbon (2017), and Buenos Aires (2019). The next one will be held in Barcelona in 2021.

3. The reaction of the Barcelona City Council officials to the sight of the commercial atlas map was most irate, as they considered that the municipality's interest in the periphery, where much had been invested, was neglected. But the map only represents the result of a policy of architectural type that prioritizes 
antiquity over any other criterion; establishments of this type could not exist in districts with less than fifty years of history and a lower socio-economic level. Killing the messenger, in this case, the faithful cartographic representation of the data, is inappropriate, and the map was published (Carreras, 2003; pp. 138-139).

4. Dubai is first in the list with 4,668 euros of expenditure per international tourist and resident inhabitant. These figures are mainly explained by the small municipal area and, therefore, the city's inhabitants in relation to its metropolitan area.

5. The remaining euros amounting to 189 euros per day spent per tourist (the highest figure in Spain according to the "Tourist Expenditure Survey" of the INE) comprise accommodation, transport, food and primarily tickets to monuments. The total expenditure of international tourists who visited Barcelona during May 2016 reached the sum of 1.541 billion euros, during the first five months of the year the figure reached 5.238 billion euros. If we look at the average daily expenditure per tourist, the figure rises to the 189 euros per day mentioned above.

6. The first large commercial study of the city of Barcelona in the first half of the 1980s was subtitled with the slogan: Barcelona city of shopping (Carreras, Domingo, Sauer, 1990).

7. Public buildings (schools, hospitals, administration) and religious buildings also have a similar role, but their conservation is the exclusive competence of their administrations, which does not prevent their demolition or renovation with greater negative consequences for the collective thinking of citizens.

\section{REFERENCES}

AA.VV. (1999). Barcelona, posa't guapa. Tretze anys. Barcelona: Ajuntament de Barcelona, p.296. Ajuntament de Barcelona. (2014). El comerç a Barcelona (p.175).

Ajuntament de Barcelona. (2015). Catàleg de patrimoni arquitectònic, històric-artístic i paisatjístic dels establiments emblemátics de La ciutat de Barcelona. Ajuntament de Barcelona, 2016.

Ascana. (2008-2016). Informe locales comerciales. Madrid: Ascana Expansión.

Bernardos, G., Martínez-Rigol, S., Frago, L., \& Carreras, C. (2014). Las apropiaciones de la ciudad a la hora de la globalización: las estrategias del capital ruso y chino en el mercado inmobiliario de Barcelona. In Scripta Nova, Barcelona: Universitat de Barcelona, 18 [493(52), 1-17].

Capel, H. (2005). El modelo Barcelona, un examen crítico. Barcelona: Ediciones El Serbal.

Carreras, C. (1989). Per una nova geografía commercial. In Revista Catalana de Geografia [IV(10), 5-

16]. Barcelona: ICC.

Carreras, C. (2001). La universitat i la Ciutat (p.68). Barcecelona: Aula Barcelona.

Carreras, C. (2003). Atles comercial de Barcelona. Barcelona: Ajuntament de Barcelona.

Carreras, C. (2012). De modelos urbanos: una revisión histórica a partir del caso de Barcelona. In Boletín de la Real Sociedad Geogràfica (CXLVIII, 183-204). Madrid.

Carreras, C. (2015). For a more critical Consumption history. In L. D'Alessandro.

Carreras, C., Domingo, J., \& Sauer, C. (1990). Les àrees de concentració comercial de Barcelona. Barcelona ciutat de compres. Barcelona: Institut Cartogràfic de Catalunya.

Carreras, C. (2016). New spaces and times of consumption in Barcelona: the case of Raval. GeotemaAGEI, 51, 32-41.

Carreras, Moreno, \& Ariño. (2006). Las tiendas históricas de Cataluña.

Choay, F. (1980). La Règle et le Modèle : Sur la théorie de l'architecture et de l'urbanisme, Paris, $\underline{\text { Seuil }}$

D’Alessandro, L. (2015). City, Retail and Consumption. Napoli: Università degli Studi di Napoli "L'Orientale", pp. 478.

Ferrer, F. (2001). El Paisatge urbà, un punt de trobada (p.95). Barcelona: Universitat de Barcelona.

Frago, L. (2011). La metamorfosi del centre a les capitals comarcals: entre tradició i postmodernitat. Doctoral thesis. Barcelona:Universitat de Barcelona.

Hedrick-Wong, Y., \& Choong, D. (2015). MasterCard Global destination cities Index. New York: MasterCard.

Lynch, K. (1960). The Image of the City. Cambridge, Mass.: The Massachusetts Institute of Technology Press. 
Moreno, S. (2011). Aproximación teórica y práctica a las relaciones entre comercio y ciudad. El caso de la producción y el consumo de libros en la ciudad de Barcelona. Doctoral thesis. Barcelona: Universitat de Barcelona.

Philipose, S. (2019). Retail Apocalypse. The Death of Malls, Retailers and Jobs. Independently Published.

Tafunell, X. (1989). La construcción residencial en el crecimiento residencial de Barcelona (1854-1897). Barcelona: Universitat Autònoma de Barcelona; Doctoral thesis. 